\title{
The Effect of Countries' Geographical Characteristics on Income
}

\author{
Seham H. Negem \\ Tanta University, \\ Faculty of Commerce
}




\title{
The Effect of Countries' Geographical Characteristics on Income Seham H. Negem Tanta University, Faculty of Commerce
}

\begin{abstract}
It is known that the countries' geographic characteristics are not affected by their incomes, or by government policies and other factors that influence income and it is difficult to think of reasons that a country's geographic characteristics could have effects on its income except through their impact on trade. Despite it seems there is no correlation with the other determinants of income. The object of this paper therefore is to examine the direct relationship between geographical variables and per worker income using a derived equation for this relationship based on Frankel and Romer (1999) model to determine the bilateral trade. The results provide that geographic variables have significant effects on income. Distance has a significant negative impact on income via its negative impact on bilateral trade; the estimated elasticity of income with respect to distance is less (in absolute value) than -1. Income of a country is increasing in its trading partner's size. And if one of the countries is landlocked, income falls by about a tenth. The coefficients on the common border variable are estimated precisely as about third of country pairs share a border (European Union\& Middle East countries). The estimates imply that sharing a border has a considerable impact on country income via its influence on bilateral trade with its trading partner. The presence of a common border alters, a little bit, the effects of the some variables and a lot for the others. For example, the estimated elasticity with respect to country's trading partner population across a shared border is 0.43 rather than 0.40 , and the estimated elasticity with respect to distance is 0.652 (with positive sign) rather than -0.223 . The results obtained are quite interesting and draw a conclusion about the important role geographical variables play in explaining income per worker.
\end{abstract}

Key words: Bilateral trade, European Union, Geography, Income per worker, \& Middle East Countries. 


\section{Introduction}

A debate about geography importance and the channels through which geography acts has engaged largely in recent aggregate economic outcomes discussion. Many authors have been engaged in this debate like Frankel and Romer (1999), Torres and Mendez (2000), Overman et al., (2001), Sachs (2003), Rodrik et al. (2004), Feyrer (2009), and Ngeleza (2011). They tested whether geography affects economic activity through direct channels such as geography impacts on productivity, population growth, trade and investment or through influences on the political and economic institutions choice which represents the indirect channels. As stated by Overman et al. (2001), both first-and second- nature geography are major determinants of production structure, trade and income. First-nature is defined as the physical geography of coasts, mountains, and endowments of natural resources while second-nature is the geography of distance between economic agents (for more details, see Overman et al., 2001, 2).

According to Feyrer (2009), the distance between two countries has, empirically, a strong influence on the volume of bilateral trade; this is the idea of the gravity model. Because distance alters trade costs, the imports and exports of a country can depend on its neighbours. Having rich neighbours can increase demand for your exports. Moreover, it can allow you access to cheaper inputs into production (Manners and Behar, 2007). It is known that transactions costs are directly increased by distance. It creates time costs and information barriers costs (information about remote economies).

To determine the relationship between geographical variables and income per capita, income per capita growth, population density and population growth in Colombian municipalities, Torres and Mendez (2000) found that geography affects both the level of municipal income per capita and its growth. They established that, among the geographic variables, distance to domestic markets and soil type exercise the greatest influence on income per capita and its growth. In a series of papers Sachs (2003) has demonstrated the strong correlation between one levels of per capita income, economic growth, and other economic and demographic dimensions on one side and on the other side are geographical and ecological variables such as distance from the coast, disease ecology, and climate zone. 
Sachs (2003) showed the direct effect of malaria transmission, strongly affected by ecological conditions, on the per capita income level after controlling for the quality of institutions. Rodrik et al. (2004) estimated the respective contributions of institutions, geography, and trade in determining income levels around the world, using instrumental variables for institutions and trade. According to Rodrik et al. (2004), geography is a key determinant of climate, endowment of natural resources, disease burden, transport costs, and diffusion of knowledge and technology from more advanced areas. Although their results have a strong indirect influence on agricultural productivity and the quality of human resources, one of their results indicated that measures of geography have at best weak direct effects on incomes.

By estimating models similar to those of Rodrik et al. (2004), who consider three basic determinants of current per capita income: institutional quality (INST), openness to international trade (TRADE), and Geography, Bleaney and Dimico (N.A.) decisively rejected the hypothesis that geographical factors influence long-run only indirectly, through the quality of institutions. They have shown that geography has a significant direct impact on long-run development. Their findings are robust to the inclusion of dummies for sub-Saharan Africa or oil production, to the extension of the sample from ex-colonies to all countries, and to the replacement of the usual instrument (settlers' mortality) by stronger instruments for institutional quality (latitude, the share of the country in the temperate climatic zone).

By testing a series of prominent hypotheses regarding how institutions, geography, and trade interact to influence income per capita, Ngeleza (2011) used a novel spatial econometric approach to control for both spillovers among neighbouring countries and spatially correlated omitted variables. Ngeleza (2011) used simultaneous equations to identify alternative channels through which country characteristics might affect income through trade and institutions. Evidence indicated that geographic variables such as whether a country is landlocked and its distance to the equator have strong independent effects on income by facilitating trade through easy access and proximity to larger markets. 
Based on Frankel and Romer (1999) model to determine the relationship between bilateral trade and geography, the purpose of this paper is to examine the impact of geographical variables on income per worker via their effects on trade, as geography is an important determinant of both international and within-country trade, despite it seems there is no correlation with the other determinants of income. However, trade affects income through different channels such as comparative advantage, specialization, exploitation of increasing returns from larger markets, exchange of ideas through communication and travel, and spread of technology through investment and exposure to new goods (for more details, see Ngeleza, 2011). So, our paper proposes geography as an instrument for trade.

This paper introduces two main contributions. The first is to link, directly, both geographical factors and income per capita by using an equation derived from Frankel and Romer (1999) model. The second one is to use data of both the Middle East countries and European Union to estimate our model. The Middle East countries, especially the Mediterranean ones, are of considerable economic significance for the European Union, constituting as a group one of its largest trading partners. Since the 1960s relations between the community/union and the Mediterranean countries have become closer, strengthened in November 1995. The so-called "Barcelona process" was re-launched in July 2008 as the union for the Mediterranean.

The partnership now includes all 28 member states of European Union, along with 15 partners across the southern Mediterranean and the Middle East: Albania, Algeria, Bosnia\& Herzegovina, Egypt, Israel, Jordan, Lebanon, Libya, Mauritania, Monaco, Montenegro, Morocco, Occupied Palestinian territories, Syria, Tunisia and Turkey ( for more details, see EUROPEDIA.MOUSSIS.EU). Under the Euro-Mediterranean Partnership Association agreements have been concluded with three Maghreb countries, Tunisia (Agreement, last amended by decision 2006/612), Morocco (Agreement and decision 2000/204, last amended by agreement and decision 2012/497) and Algeria (agreement, last amended by protocol 6 ).

Also, association agreements have been concluded with Mashreq countries, Egypt (agreement, last amended by protocol), Jordan (Agreement, last amended by decision 2006/508) and Lebanon (Agreement and decision 2006/356). One of the most important 
provisions of these agreements is the establishment of a free trade area. To promote trade between Iraq and the Union is included in a partnership agreement between the two parties as well (EUROPEDIA.MOUSSIS, EDU.).

By the 1975 agreement, preferential arrangements for Israel were introduced. These arrangements are operating well and resulting in steady growth in trade between the European Community/ Union and Israel. An agreement, amended in 2005, on trade and cooperation has been concluded between the European community and the Palestine Liberation Organisation (PLO) for the Palestinian authority benefit. Commercial relations are covered and stages leading to full trade liberalisation between both sides are set out. On 5 April 2005 the EU and the Gulf Cooperation Council (GCC) were committed to concluding negotiations on a free-trade agreement after formalising economic, including trade promotion, and political relations between the two parties on June 15, 1988.

The remainder of this paper is organised as follows: Section 2 discusses the model specification, illustrating how the equation we estimate is derived. Section 3 presents the data and provides an exploratory empirical assessment of the key variables. Section 4 concludes.

\section{Model specification}

Based on Frankel and Romer (1999) to estimate the bilateral trade equation in terms of geographical characteristics, a three-equation model is used. The first equation concerns the income function where income is a function of economic interactions within the country (within-country trade), residents trade with one another, economic interactions with the other countries (international trade), residents trade with foreigners, and other factors as follows:

$\ln Y_{i}=\alpha+\beta I_{i}+\lambda W_{i}+\varepsilon_{i}$

Where, $Y_{i}$ is income per capita, $I_{i}$ is international trade, $W_{i}$ is within-country trade, $\varepsilon_{i}$ represents the other effects on income. The vast literature on trade and its enhancing effect on income dates back at least to Smith (1776), who argued that trade is important as a vent for surplus production and as a means of extending the market. Consequently, the division of labour and the level of productivity improve. In his view, foreign trade encourages improvement of the country's productive powers and 
augmentation of the country's production to the utmost, thereby increasing the real revenue of wealth and society.

According to Thirlwall (2000), in the $19^{\text {th }}$ century, Smith's doctrine developed into an export-drive argument, particularly in the colonies, which explains why classical trade theory is often associated with colonialism. Ricardo (1817) developed the theory of comparative advantage, indicating that under the assumptions of perfect competition and the full employment of resources, welfare gains, which are static, can be reaped by specialising in the production of goods which have the lowest opportunity cost and trading the surplus of production over domestic demand. These static gains are derived from the reallocation of resources from one sector to another as increased specialisation, based on comparative advantage, occurs.

There are trade creation gains that arise within customs unions or free trade areas as the barriers to trade are removed between members, but the gains are once-for-all. Once the tariff barriers have been removed, and no further reallocation takes place, the static gains are exhausted (Thirlwall, 2000). In Thirlwall's (2000) view, trade brings several dynamic benefits, among them that the broadening of the total market for a country's producers, by exports. If production is subject to increasing returns, export growth becomes a continual source of productivity growth. Increasing returns also contribute in the accumulation of capital. A small, non-trading country has very little scope for large-scale investment in advanced capital equipment; the small market inhibits specialisation. Trading, in contrast, opens up the possibility of industrialisation and moving away from traditional methods of production. Export markets allow the production of many goods that would otherwise not be economically viable.

Other important dynamic benefits from trade include the stimulus to competition; the transfer of knowledge, ideas and technical know-how; the possibility of accompanying capital flows through foreign direct investment, and changes in attitudes and institutions. The "new" growth theory views such gains as forms of externalities, which prevent decline in the marginal product of physical capital. Thus, trade enhances the long-term national economic growth. 
Haberler (1964), among others, pointed out the following important beneficial effects that international trade can have on economic development:

(1) Trade can lead to full utilisation of otherwise under-employed domestic resources.

(2) By expanding the size of the market, trade makes possible division of labour and economies of scale.

(3) International trade is the vehicle for the transmission of new ideas, new technology, and new managerial and other skills.

(4) Trade also stimulates and facilitates the international flow of capital from developed to developing countries.

(5) The importation of new manufactured products can stimulate domestic demand until efficient domestic production of these goods becomes feasible.

(6) Trade stimulates greater efficiency by domestic producers to meet foreign competition. This is particularly important to keep low the cost and price of intermediate products used as inputs in the domestic production of other commodities.

The other two equations concern the determinants of both international and within-country trade. International trade is, mainly, a function of the proximity of a country to other countries:

$I_{i}=\phi+\psi P_{i}+\delta_{i}$

Where, $I_{i}$ is, as stated above, international trade, $P_{i}$ is a country's proximity to other countries, and $\delta_{i}$ is the other effects on international trade.

Equally, within-country trade is a function of country's size:

$W_{i}=v+\omega S_{i}+\gamma_{i}$

Where, $W_{i}$ is, as stated above, within-country trade, $S_{i}$ is a country's size, and $\gamma_{i}$ is the other effects on within-country trade. 
Based on Farnkel and Romer (1999), the residuals of the three equations, $\varepsilon_{i}, \delta_{i}, \& \gamma_{i}$, are likely to be correlated. Also, countries' geographic characteristics $P_{i}{ }^{\prime} s \& S_{i}{ }^{\prime} s$, are not correlated with $\varepsilon_{i}$. Given the above assumption, equation (1) would be estimated by data on $\mathrm{Y}, \mathrm{I}, \mathrm{W}, \mathrm{P}, \& \mathrm{~S}$ by instrumental variables as both $\mathrm{P} \& \mathrm{~S}$ are correlated with I \& W.

To address the problem, likely the work of Frankel and Romer (1999), equation (3) is substituted into equation (1).

$\ln Y_{i}=\alpha+\beta I_{i}+\lambda\left(v+\omega S_{i}+\gamma_{i}\right)+\varepsilon_{i}$

$\ln Y_{i}=\alpha+\beta I_{i}+\lambda v+\lambda \omega S_{i}+\lambda \gamma_{i}+\varepsilon_{i}$

$\ln Y_{i}=(\alpha+\lambda v)+\beta I_{i}+\lambda \omega S_{i}+\left(\lambda \gamma_{i}+\varepsilon_{i}\right)$

According to Frankel and Romer (1999), the Bilateral Trade Equation:

$\ln \left(\tau_{i j} / G D P_{i}\right)=a_{0}+a_{1} \ln D_{i j}+a_{2} \ln S_{i}+a_{3} \ln S_{j}+e_{i j}$

Where,

$\tau_{i}$ is bilateral trade, international trade, between i\&j (measured as exports+imports), $D_{i j}$ is the distance between them, and $S_{i} \& S_{j}$ are their sizes.

We include both log population and log area as a two measures of size. Whether countries are landlocked and whether they have a common border affect trade. Dummy variables for these factors are used. Countries' trade with immediate neighbours which is include with the common-border dummy.

So,

$$
\begin{aligned}
& \ln \left(\tau_{i j} / G D P_{i}\right)=a_{0}+a_{1} \ln D_{i j}+a_{2} \ln P O P_{i}+a_{3} \ln A_{i}+a_{4} \ln P O P_{j}+a_{5} \ln A_{j}+a_{6}\left(L_{i}+L_{j}\right) \\
& +a_{7} B_{i j}+a_{8} B_{i j} \ln D_{i j}+a_{9} B_{i j} \ln P O P_{i}+a_{10} B_{i j} \ln A_{i}+a_{11} B_{i j} \ln P O P_{j}+a_{12} B_{i j} \ln A_{j}+ \\
& a_{13} B_{i j}\left(L_{i}+L_{j}\right)+e_{i j}
\end{aligned}
$$

Where, POP is population, A is area, L is a dummy for landlocked countries, and B is a dummy for a common border between two countries. Equation (8) is substituted into equation (6) with including both log population and log area as a two measures of size to replace $S_{i}$. 
$\ln Y_{i}=(\alpha+\lambda v)+\beta\left(a_{0}+a_{1} \ln D_{i j}+a_{2} \ln P O P_{i}+a_{3} \ln A_{i}+a_{4} \ln P O P_{j}+a_{5} \ln A_{j}+a_{6}\left(L_{i}+L_{j}\right)\right.$

$+a_{7} B_{i j}+a_{8} B_{i j} \ln D_{i j}+a_{9} B_{i j} \ln P O P_{i}+a_{10} B_{i j} \ln A_{i}+a_{11} B_{i j} \ln P O P_{j}+a_{12} B_{i j} \ln A_{j}+$

$\left.a_{13} B_{i j}\left(L_{i}+L_{j}\right)+e_{i j}\right)+\lambda \omega \ln P O P_{i}+\lambda \omega \ln A_{i}+\left(\lambda \gamma_{i}+\varepsilon_{i}\right)$

So,

$\ln Y_{i}=(\alpha+\lambda v)+a_{0} \beta+a_{1} \beta \ln D_{i j}+a_{2} \beta \ln P O P_{i}+a_{3} \beta \ln A_{i}+a_{4} \beta \ln P O P_{j}+a_{5} \beta \ln A_{j}+a_{6} \beta\left(L_{i}+L_{j}\right)$

$+a_{7} \beta B_{i j}+a_{8} \beta B_{i j} \ln D_{i j}+a_{9} \beta B_{i j} \ln P O P_{i}+a_{10} \beta B_{i j} \ln A_{i}+a_{11} \beta B_{i j} \ln P O P_{j}+a_{12} \beta B_{i j} \ln A_{j}+$

$a_{13} \beta B_{i j}\left(L_{i}+L_{j}\right)+\beta e_{i j}+\lambda \omega \ln P O P_{i}+\lambda \omega \ln A_{i}+\left(\lambda \gamma_{i}+\varepsilon_{i}\right)$

By rearranging,

$\ln Y_{i}=\left(\alpha+a_{0} \beta+\lambda v\right)+a_{1} \beta \ln D_{i j}+\left(a_{2} \beta+\lambda \omega\right) \ln P O P_{i}+\left(a_{3} \beta+\lambda \omega\right) \ln A_{i}+a_{4} \beta \ln P O P_{j}+$

$a_{5} \beta \ln A_{j}+a_{6} \beta\left(L_{i}+L_{j}\right)+a_{7} \beta B_{i j}+a_{8} \beta B_{i j} \ln D_{i j}+a_{9} \beta B_{i j} \ln P O P_{i}+a_{10} \beta B_{i j} \ln A_{i}+a_{11} \beta B_{i j} \ln P O P_{j}+$

$a_{12} \beta B_{i j} \ln A_{j}+a_{13} \beta B_{i j}\left(L_{i}+L_{j}\right)+\left(\lambda \gamma_{i}+\beta e_{i j}+\varepsilon_{i}\right)$

So, the equation we estimate is:

$\ln Y_{i}=\theta_{0}+\theta_{1} \ln D_{i j}+\theta_{2} \ln P O P_{i}+\theta_{3} \ln A_{i}+\theta_{4} \ln P O P_{j}+$

$\theta_{5} \ln A_{j}+\theta_{6}\left(L_{i}+L_{j}\right)+\theta_{7} B_{i j}+\theta_{8} B_{i j} \ln D_{i j}+\theta_{9} B_{i j} \ln P O P_{i}+\theta_{10} B_{i j} \ln A_{i}+\theta_{11} B_{i j} \ln P O P_{j}+$

$\theta_{12} B_{i j} \ln A_{j}+\theta_{13} B_{i j}\left(L_{i}+L_{j}\right)+\mu_{i j}$

The above equation can be obtained by another way as follows: where unlikely the work of Frankel and Romer (1999), equations (2) \& (3) are substituted into equation (1).

$$
\begin{aligned}
\ln Y_{i} & =\alpha+\beta\left(\phi+\psi P_{i}+\delta_{i}\right)+\lambda\left(v+\omega S_{i}+\gamma_{i}\right)+\varepsilon_{i} \\
& =\alpha+\beta \phi+\beta \psi P_{i}+\beta \delta_{i}+\lambda v+\lambda \omega S_{i}+\lambda \gamma_{i}+\varepsilon_{i} \\
& =(\alpha+\beta \phi+\lambda v)+\beta \psi P_{i}+\lambda \omega S_{i}+\left(\beta \delta_{i}+\lambda \gamma_{i}+\varepsilon_{i}\right)
\end{aligned}
$$

Thus, we can obtain equation (9) by replacing two measures of the size which are population and area and using distance and dummy variables of border and landlocked to represent proximity.

\section{Data and exploratory results}

A cross-section of the European Union and the Middle East countries is estimated. Our data are for 2012, covering 48 countries (excluding Croatia; its year of entry 2013). This paper uses data only in levels (not in growth). Economic data are drawn from Penn 
World Tables 6.2, which is distributed by the National Bureau of Economic Research, for countries' national income (real GDP, per worker, indexed, in 2000 U.S. dollars). Labour, employment, was obtained using the national accounts data of labour force (total) from the WDI, CD-ROM of the World Bank and the annual reports of the Central Banks to calculate income per worker.

To estimate the effect of the size, two natural measures are used. These measures are population and area (both in $\operatorname{logs}$ ). Population data, like GDP, are drawn from Penn World Tables 6.2, representing the total number of people. The information on areas, common borders, and landlocked countries is from CIA Factbook. Whether a country is landlocked is a dummy variable, taking the value one if the country is landlocked and zero otherwise.

The existence of a common border between two countries is represented by a dummy variable as well. This variable takes the value one if there is a common border between two countries and zero otherwise. Finally, distance is measured as the distance between countries' capital cities (commonly the main ports). The data for distance are obtained from the CEPII. The CEPII provide several different variations for measuring the distance between countries (distance between countries is available in some variations: between the populous cities, between capital cities, as used for our paper, and population weighted distances between countries where using city level data to incorporate the internal distribution of population). In interpreting the results concerning the variable's interaction with the common-border dummy, we focus on the sum of the coefficients on the variable and on its interaction with the common-border dummy.

Our model was estimated by Ordinary Least Squares (OLS), using Givewin/PcGive of Doornik and Hendry (2003), for European Union and Middle East countries crosssection data of income $\left(Y_{i}\right)$, distance between two countries having bilateral trade $\left(D_{i j}\right)$, population $(P O P)$, area $(A)$, a dummy for landlocked countries $(L)$, and a dummy for a common border between two countries $(B)$. The results are presented in table 1 . The first column shows the estimated coefficients and their standard errors on the variables. The common-border dummy, $B_{i j}$, and its interactions estimates are reported in the second column. It should be noted that all the variables are estimated in logarithmic form and so 
the analysis of the data does not depend on raw coefficients, but depends on elasticities. All the coefficients represent elasticities.

Table 1

Ordinary Least Squares (OLS) Estimates, 2012.

\begin{tabular}{|c|c|c|}
\hline Regressors & Estimated Coefficient & Interaction \\
\hline Constant & $\begin{array}{l}-8.371 \\
(0.026)\end{array}$ & $\begin{array}{l}-\mathbf{0 . 0 2 1} \\
(0.657)\end{array}$ \\
\hline$L D i j$ & $\begin{array}{l}-0.223 \\
(0.020)\end{array}$ & $\begin{array}{l}0.875 \\
(0.4884)\end{array}$ \\
\hline$\angle P O P i$ & $\begin{array}{r}-0.773 \\
(0.205) \\
\end{array}$ & $\begin{array}{l}-0.483 \\
(0.5355)\end{array}$ \\
\hline$L A i$ & $\begin{array}{l}-0.167 \\
(0.141)\end{array}$ & $\begin{array}{l}--0.507 \\
(0.4520)\end{array}$ \\
\hline$L P O P j$ & $\begin{array}{l}0.401 \\
(0.252)\end{array}$ & $\begin{array}{l}\mathbf{0 . 0 3 0 0 2} \\
(6.355 \mathrm{e}-007)\end{array}$ \\
\hline$L A j$ & $\begin{array}{c}-0.208 \\
(0.162) \\
\end{array}$ & $\begin{array}{l}-0.247 \\
(0.3019) \\
\end{array}$ \\
\hline$(L i+L j)$ & $\begin{array}{c}\mathbf{- 0 . 0 7 7} \\
(0.771) \\
\end{array}$ & $\begin{array}{l}0.078 \\
(1.110) \\
\end{array}$ \\
\hline Sample size & 624 & \\
\hline$R^{2}$ & 0.63 & \\
\hline
\end{tabular}

Notes:

-see Appendix 1 for t- statistics of the variables. the critical values at 5\%, 1\%, and $10 \%$ significance level are $\mathbf{- 1 . 6 6 , - 2 . 3 6}$ and $\mathbf{- 1 . 2 9}$, respectively.

-Standard errors are in parentheses.

- The dependent variable is $\ln \left(Y_{i}\right)$.

- The first column reports the coefficient on the variable listed, and the second one reports the coefficient on the variable's interaction with the common-border dummy: the variable are $B i j$, BijlnDij, BijlnPOPi, $B i j I n A i, B i j I n P O P j, B i j I n A j$, and $B i j(L i+L j)$ respectively.

First of all we can confirm that these coefficients are statistically significant (see Appendix 1 for $\mathrm{t}$ - statistics of the variables) at the 5\%,1\%, and $10 \%$ significance level. $\mathrm{R}^{2}$ for our equation shows that a reasonable proportion $(63 \%)$ of the variations in the dependent variable is explained by explanatory variables (Regressors). Income $\left(Y_{i}\right)$ is the dependent (endogenous) variable. The independent ones, (as stated), are distance between two countries having bilateral trade $\left(D_{i j}\right)$, population $(P O P)$, area $(A)$, a dummy for landlocked countries $(L)$, and a dummy for a common border between two countries $(B)$ 
and the variables interacted with the common-border dummy: the variable are $B i j$, BijlnDij , BijlnPOPi, BijlnAi, BijlnPOPj, BijlnAj , and Bij(Li+Lj).

Via their effects on bilateral trade the effects of geographic variables on income are indicated as follows. Distance has a significant negative impact on income via its negative impact on bilateral trade; the estimated elasticity of income with respect to distance is less (in absolute value) than -1. Income of country $\boldsymbol{i}$ is increasing in $\boldsymbol{j}$ 's size; the elasticity with respect to country $\boldsymbol{j}$ 's population is about 0.4. In addition, income is decreasing in $\boldsymbol{i}$ 's size and in $\boldsymbol{j}$ 's area. And if one of the countries is landlocked, income falls by about a tenth. It is noted that the effect of landlocked variable is small compared with the influence of the other geographic variables on country $i$ 's income.

The coefficients on the common border variable are estimated precisely as about third (reasonable fraction) of country pairs share a border (European Union\& Middle East countries). The estimates imply that sharing a border has a considerable impact on country $\boldsymbol{i}$ 's income via its influence on bilateral trade with country $\boldsymbol{j}$. The presence of a common border alters, a little bit, the effects of the some variables and a lot for the other ones. For example, the estimated elasticity with respect to country $\boldsymbol{j}$ 's population across a shared border is 0.43 rather than 0.40 , and the estimated elasticity with respect to distance is 0.652 (with positive sign) rather than -0.223 . That is because most of the countries included in our sample have a common-border with each other. To sum up, the results obtained are quite interesting and draw a conclusion about the important role geographical variables play in explaining income per worker.

\section{Conclusion}

Attempting to take a fresh look at geography and its influence on income, the objective of this paper is to determine the direct relationship between geographical variables and real per worker income. This paper uses cross-sectional data in a derived equation based Frankel and Romer (1999) model to explore how measured geography might be linked to real per worker income. This offers a contribution for how directly geographical characteristics affect its income. The endogenous variable is income (measured by per worker income). The exogenous variables represent geographic characteristics (affecting bilateral trade). 
These variables are distance, population, area, a dummy for landlocked countries, and a dummy for a common border between two countries. Most notably, both population and area represent countries' size that affects income via its effect on withincountry trade. We found that geography affects the level of per worker income, explaining $63 \%$ of its variation. It was established that, amongst the geographical variables, distance has a significant negative impact on income via its negative impact on bilateral trade; the estimated elasticity of income with respect to distance is less (in absolute value) than -1 . Income of country is increasing in its trading partner's size; the elasticity with respect to country trading partner's population is about 0.4 . In addition, income is decreasing in country's size and in its trading partner's area. And if one of the countries is landlocked, income falls by about a tenth. It is noted that the effect of landlocked variable is small compared with the influence of the other geographic variables on country's income.

The coefficients on the common border variable are estimated precisely as about third of country pairs share a border (European Union\& Middle East countries). The estimates imply that sharing a border has a considerable impact on country $\boldsymbol{i}$ 's income via its influence on bilateral trade with country's trading partner. The presence of a common border alters, a little bit, the effects of the some variables and a lot for the other ones. For example, the estimated elasticity with respect to country's trading partner population across a shared border is 0.43 rather than 0.40 , and the estimated elasticity with respect to distance is 0.652 rather than -0.223 . That is because most of the countries included in our sample have a common-border with each other. 


\section{Appendix 1}

\section{The significance of the regression}

\begin{tabular}{|l|c|}
\hline The regressor & t-statistics \\
\hline constant & -2.27 \\
\hline LDij & -1.81 \\
\hline LPOPi & 2.35 \\
\hline LAi & -1.78 \\
\hline LPOPj & 1.69 \\
\hline LAj & -1.82 \\
\hline Li+Lj & -1.30 \\
\hline Bij & -2.23 \\
\hline BijlnDij & 1.79 \\
\hline BijlnPOPi & -1.90 \\
\hline BijlnAi & 1.29 \\
\hline BijlnPOPj & 2.07 \\
\hline BijlnAj & -2.19 \\
\hline Bij(Li+Lj) & 1.37 \\
\hline
\end{tabular}




\section{Appendix 2}

\section{The Middle East Countries (Traditional Definition)}

\begin{tabular}{|l|l|l|l|}
\hline Ser. & Country & The main port & The capital city \\
\hline 1. & Algeria & Algiers & Algiers \\
2. & Bahrain & Mina Salman & Manama \\
3. & Egypt & Ayn Sukhnah & Cairo \\
4. & Iran & Assaluyeh & Tehran \\
5. & Iraq & Al Basra & Baghdad \\
6. & Israel & Ashdod & Jerusalem (Tel Aviv) \\
7. & Jordan & Al Aqabah & Amman \\
8. & Kuwait & Ash Shu'uybah & Kuwait city \\
9. & Lebanon & Beirut & Beirut \\
10. & Libya & Az Zawiyah & Tripoli \\
11. & Morocco & Casablanca & Rabat \\
12. & Oman & Sultan Qaboos & \\
13. & Palestine & Jaffa & Muscat \\
14. & Qatar & Doha & Jerusalem (Ram Allah) \\
15. & Saudi Arabia & Ad dammam & Doha \\
16. & Sudan & Bur Sudan & Riyadh \\
17. & Syria & Baniyas & Khartoum \\
18. & Tunisia & Bizerte & Damascus \\
19. & Turkey & Aliaga & Tunis \\
20. & United Arab Emirates & Al Fujayrah & Ankara \\
21. & Yemen & Aden & Abu-Dhabi \\
& & & Sanaa \\
& & & \\
\hline Source: & & \\
\hline
\end{tabular}

Source: CIA, The World Factbook 


\section{Appendix 3}

\section{The European Union Countries}

\begin{tabular}{|c|c|c|c|c|}
\hline Ser. & Country & Year of entry & The main port & The capital city \\
\hline 1. & Austaria & 1995 & Enns, Vienna & Vienna \\
\hline 2. & Belgium & 1952 & Antwerp, & Brussels \\
\hline 3. & Bulgaria & 2007 & Zeebrugge & Sofia \\
\hline 4. & Croatia & 2013 & Burgas, Varna & Zagreb \\
\hline 5. & Cyprus & 2004 & Rijeka & Nicosia \\
\hline 6. & Czech Republic & 2004 & Larnaca, & Prague \\
\hline 7. & Denmark & 1973 & Famagusta & Copenhagen \\
\hline 8. & Estonia & 2004 & Decin, Prague & Tallinn \\
\hline 9. & Finland & 1995 & Aalborg, Aarhus & Helsinki \\
\hline 10. & France & 1952 & Kuivastu & Paris \\
\hline 11. & Germany & 1952 & Helsinki & Berlin \\
\hline 12. & Greece & 1981 & Calais, Paris & Athens \\
\hline 13. & Hungary & 2004 & Bremn & Budapest \\
\hline 14. & Ireland & 1973 & Agioi Theodoroi & Dublin \\
\hline 15. & Italy & 1952 & Budapest & Rome \\
\hline 16. & Latvia & 2004 & Cork & Riga \\
\hline 17. & Lithuania & 2004 & Augusta & Vilnius \\
\hline 18. & Luxembourg & 1952 & Riga & Luxembourg \\
\hline 19. & Malta & 2004 & Klaipeda & Valletta \\
\hline 20. & Netherlands & 1952 & Mertert & Amsterdam \\
\hline 21. & Poland & 2004 & Marsaxlokk & Warsaw \\
\hline 22. & Portugal & 1986 & Amsterdam & Lisbon \\
\hline 23. & Romania & 2007 & Gdansk & Bucharest \\
\hline 24. & Slovakia & 2004 & Lisbon & Bratislava \\
\hline 25. & Slovenia & 2004 & Braila & Ljubljana \\
\hline 26. & Spain & 1986 & Bratislava & Madrid \\
\hline 27. & Sweden & 1995 & Koper & Stockholm \\
\hline 28. & United Kingdom & 1973 & $\begin{array}{l}\text { Algeciras } \\
\text { Brofjorden } \\
\text { Dover }\end{array}$ & London \\
\hline
\end{tabular}

Source:CIA, The World Factbook 


\section{Appendix 4}

The First Countries' Trading Partners

\begin{tabular}{|c|c|c|}
\hline Ser. & Country & The First Trading partner \\
\hline 1. & Austaria & Germany (x), Germany (m) \\
\hline 2. & Belgium & Germany (x), Netherlands (m) \\
\hline 3. & Bulgaria & Germany (x), Russia (m) \\
\hline 4. & Croatia & Italy (x\&m) \\
\hline 5. & Cyprus & Greece $(\mathrm{x})$, Greece $(\mathrm{m})$ \\
\hline 6. & Czech Republic & Germany (x), Germany (m) \\
\hline 7. & Denmark & Germany (x), Germany (m) \\
\hline 8. & Estonia & Sweden (x), Finland (m) \\
\hline 9. & Finland & Sweden (x), Russia (m) \\
\hline 10. & France & Germany (x), Germany (m) \\
\hline 11. & Germany & $\mathrm{UK}^{*}$ \\
\hline 12. & Greece & Italy (x), Germany (m) \\
\hline 13. & Hungary & Germany $(\mathrm{x}, \mathrm{m})$ \\
\hline 14. & Ireland & $\mathrm{US}(\mathrm{x}), \mathrm{UK}(\mathrm{m})$ \\
\hline 15. & Italy & Germany $(\mathrm{x}, \mathrm{m})$ \\
\hline 16. & Latvia & Russia (x), Lithuania (m) \\
\hline 17. & Lithuania & Russia $(x, m)$ \\
\hline 18. & Luxembourg & Germany (x), Belgium (m) \\
\hline 19. & Malta & Germany (x), Italy (m) \\
\hline 20. & Netherlands & Germany $(\mathrm{x}, \mathrm{m})$ \\
\hline 21. & Poland & Germany $(\mathrm{x}, \mathrm{m})$ \\
\hline 22. & Portugal & Spain $(\mathrm{x}, \mathrm{m})$ \\
\hline 23. & Romania & Germany $(\mathrm{x}, \mathrm{m})$ \\
\hline 24. & Slovakia & Germany $(\mathrm{x}, \mathrm{m})$ \\
\hline 25 . & Slovenia & Germany $(\mathrm{x}, \mathrm{m})$ \\
\hline 26. & Spain & France $(x)$, Germany $(\mathrm{m})$ \\
\hline 27. & Sweden & Germany $(\mathrm{x}, \mathrm{m})$ \\
\hline 28. & United Kingdom & Germany $(\mathrm{x}, \mathrm{m})$ \\
\hline 29. & Algeria & US, France \\
\hline 30. & Bahrain & Saudi Arabia $(\mathrm{x}, \mathrm{m})$ \\
\hline 31. & Egypt & Italy, US \\
\hline 32. & Iran & China, UAE \\
\hline 33. & Iraq & India, Turkey \\
\hline 34. & Israel & US $(x, m)$ \\
\hline 35. & Jordan & US, Saudi Arabia \\
\hline 36. & Kuwait & South Korea, U.S. \\
\hline 37. & Lebanon & UAE, U.S. \\
\hline 38. & Libya & Italy, Tunisia \\
\hline 39. & Morocco & France $(\mathrm{x}, \mathrm{m})$ \\
\hline 40. & Oman & China, UAE \\
\hline 41. & Palestine & Israel \\
\hline
\end{tabular}




\begin{tabular}{|l|l|l|}
\hline 42. & Qatar & Japan, U.S. \\
43. & Saudi Arabia & Japan, China \\
44. & Sudan & Macau (x,m) \\
45. & Syria & Iraq, Saudi Arabia \\
46. & Tunisia & France $(x, m)$ \\
47. & Turkey & Germany, Russia \\
48. & United Arab Emirates & Japan, India \\
49. & Yemen & China, UAE \\
\hline
\end{tabular}

Source: CIA, The World Factbook.

* The Telegraph, 12 Jan 2013.

$\mathrm{x}$ for exports \& $\mathrm{m}$ for imports. 


\section{Bibliography}

BERGGREN, N. \& JORDAHL, H., (2005), "Does Free Trade Relly Reduce Growth? Further Testing Using the Economic Freedom Index", Public Choice, 122 Spring, 99-114.

BLEANEY, M. \& DIMICO, A.,(N.A.), "Geography Matters: Reconsidering the Effect of Geography on Development", Centre for Research in Economic Development and International Trade, University of Nottingham, UK.

CHOMO, G.V., (2004), David and Goliath: The U.S.-Jordan Free Trade Agreement and the Economic Development of Jordan, United Nation.

CEPII, available at:

http://www.cepii.fr/analysisgraph/bdd/distances.htm, accessed

CIA, The World Fact book, available at:

$<$ http://www.cia.gov/cia/publications/factbook/geos/eg.html>, accessed 15/09/2012, For Croatia, 02/11/2013

EUROPEDIA.MOUSSIS.EU, available at: http://www.europedia.moussis.eu/books/book 2/7/25/05/?all=1, accessed 15/09/2013.

DOORNIK, J. A. \& HENDRY, D. F., (2003), Pc-Give Volume I-III, London, Give Win Timberlake Consultants Limited.

FEYRER, J.,(2009), "Trade and Income-Exploiting Time Series in Geography", Dartmouth College.

FRANKEL, A. J. \& ROMER, D.,(1999), "Does Trade Cause Growth", American Economic Review, 89, NO.3: 379-399.

GALLUP, J. \& SACHS, J. D.,(1998), "Geography and Economic Development", Harvard University, Harvard Institute for International Development, USA.

GLAESER, E. L., LA PORTA, R., SILANES, L. D. \& SHLEIFER, A.,(2004), "Do Institutions Cause Growth?" Economic Growth, 9, NO.3: 271-303.

HABERLER, G., (1964), "Comparative Advantage, Agricultural Production and International Trade", Journal of Agrarian Affairs, May, 130-149.

JONES, R. W. \& KENEN, P. B. (Eds.),(1984), Handbook of International Economics, Amsterdam, Elsevier Science Publishers B.V. 
KHAIR EL DIN, H., (2000), Egypt's Exports Under Liberalisation: Performance, Prospects and Constraints (1980-1998). in NASSAR, H. \& AZIZ, A. (Eds.) Egyptian Exports and Challenges of the 21st Century. Cairo, Centre for Economic and Financial Research and Studies, Cairo University.

KRUGMAN, P.,(1999), "Geography and Trade", MIT Press.

LINNEMAN, H.,(1966), "An Econometric Study of International Trade Flows", Amesterdam, North Holand.

MANNERS, P. \& BEHAR, A.,(2007), "Trade in Sub-Saharan Africa and Opportunities for Low Income Countries", World Development Report (Reshaping Economic Geography), Oxford University.

NGELEZA, G.,(2011), "Institutions, Geography, Trade, and Income per Capita: A Spatial-Simultaneous Equation Approach", International Food Policy Research Institute, IFPRI Discussion Paper 01082.

OVERMAN, H. G., REDDING, S.\&VENABLES, A.J.,(2001), "The Economic Geography of Trade, Production, and Income", London School of Economic and CEPR, NO.July.

RICARDO, D., (1817), Principles of Political Economy and Taxation, London, UK., Everyman.

RODRIK, D., SUBRAMANIAN, A. \& TREBBI, F.,(2004), "Institutions Rule: The Primacy of Institutions Over Geography and Integration in Economic Development", Feb.

SACHS, J. D.,(2003), "Institutions Don't Rule: Direct Effects of Geography on Per Capita Income", Working Paper 9490:National Bureau of Economic Research, Cambridge.

SANCHEZ, F. \& NUNEZ, J.,(1999), "Geography and Economic Development: A Municipal Approach for Colombia", IADB.

SMITH, A., (1776), An Inquiry into the Nature and Causes of the Wealth of Nations, London, UK., Strahan and Caddell.

THIRLWALL, A. P., (2000), Trade Agreements, Trade Liberalization and Economic Growth: A Survey, prepared for the African Development Report, Oxford,UK, Blackwell Publishers.

TORRES, F. S. \& MENDEZ, J. N.,(2000), "Geography and Economic Development in Colombia: A Municipal Approach", Research Network Working Paper R.408, Inter-American Development Bank. 